\title{
The Limits of Endurance: Shell Shock and Dissent in World War One
}

\author{
JOHN HORROCKS
}

\begin{abstract}
Soldiers serving on the Western Front had few opportunities to question the situation in which they found themselves. Censorship limited what they could tell people at home, though there were acceptable forms of dissent such as grumbling, jokes, poems and songs. More serious responses to the intolerable conditions of modern warfare were the nervous conditions variously described as "shell shock", concussion neurasthenia, hysteria, exhaustion, pithiatism, and psychasthenia. The need to provide treatment for many servicemen after they returned to New Zealand revealed the extent of the psychological damage among these veterans. Such consequences are now better understood in terms of concepts like post-traumatic stress, but a purely medical model of these effects can overlook the degree to which shell shock could also be an expression of an involuntary protest against military service.
\end{abstract}

It is understandable that the focus on dissent during the First World War has been on those who objected to conscription or taking part in the war. For an ordinary soldier who found himself at Gallipoli or on the Western Front, most opportunities for any form of dissent were long past. Soldiers could get drunk, gamble, visit brothels, sometimes go absent without leave or loot prisoners at the Front, but it is a stretch to call these activities forms of dissent, a rejection of the military project. These behaviours were, in fact, part of the tradition of soldiering. ${ }^{1}$

There were some forms of dissent on active service which were slightly more proactive, such as soldiers grumbling among themselves, making disrespectful jokes about superiors, writing poems or singing satirical songs - and sometimes slipping remarks into letters in the hope that they would be overlooked by the censorship authorities. Beyond minor forms of resistance such as these, there were more extreme actions available, such as desertion and self-inflicted wounding.

On the same day that the New Zealand Division stormed the Messines ridge in June, 1917, H. W. Massingham, the editor of the Unconservative Weekly, was meeting with Siegfried Sassoon in the comfortable surroundings of a London club. Massingham suggested that "if once the common soldier became articulate the War couldn't last a month."2 Massingham was wrong. For "common soldiers," the ability to express themselves was largely irrelevant. Censorship ensured that their main audience for any dissenting views came from their comrades, whereas an officer like Sassoon, with his connections with journalists and politicians, could expect his ideas to have a much wider impact. Moreover, without home leave, the New Zealand soldiers had no chance to talk over their experiences with their families. Matthew Horn, after reading letters and diaries written by New Zealand soldiers who took part in the 3rd Ypres Campaign, concluded that, while some might try to send dissentient comments through the mail, there was generally a protective aspect to soldiers' communications with home, a wish to spare their distant families from the devastation they themselves had experienced. ${ }^{3}$ 
A decade later, John A. Lee, who took part in the Messines attack, wrote about how difficult it was for soldiers to write critically about the war. In an unpublished preface written in 1930 about how he came to write his war novels, Lee tells how he had tried to write a "soldier story" in April 1918 while convalescing at Brockenhurst Hospital in the New Forest. He recalled that he was now free to say what he liked, without fear that his words could be censored or read out as a joke in an officers' mess. ${ }^{4}$ A similar observation was made in Fritz von Unruh's 1916 work, Opfergang (The Way of Sacrifice), a German expressionist perspective on the meaning of Verdun. A soldier is distressed when he loses his diary, and asks "did I go beyond the limits of permitted thoughts? Can one not express doubts? Express them surely, but not write them down, not write them down so everyone can read them." Censorship meant that Von Unruh's own work was not published until after the war.

\section{"Nervous Disintegration" and Shell Shock}

Censorship and self-censorship may have controlled written expressions of dissent, but shell shock simply overwhelmed some soldiers. "Nervous Disintegration" is the title of one of the sections of John A. Lee's semi-autobiographical novel, Civilian into Soldier. During the constant shelling after the successful attack on Messines, the hero, a New Zealand infantryman, edges towards a breakdown, hiding his incessant twitching and fears from his companions, wondering if he is a coward and hoping "To show a brave face until a shell got him. To die at least sane." Mental collapse was a lonely and shameful response.

The manifestations of breakdown gathered under the heading of shell shock included acute fear, startled reactions, amnesia, uncontrollable tremors, mutism, extreme exhaustion, a lack of confidence and hysterical paralysis. Given this variety, it is not surprising that by 1917 there were so many different therapies for shell shock that Lt. Col. Carbery, the author of the official history of the New Zealand Medical Service in the First World War, described a list of them as like reading a page from Rabelais. As the loose term "shell shock" fell out of favour, it was replaced by a multiplicity of diagnostic categories for war-induced psychoneuroses, among them concussion neurasthenia, pithiatism, hysteria, psychasthenia, and exhaustion. ${ }^{7}$

Suggested causes were equally diverse. This created such difficulty for frontline medical staff that, from mid-June 1917, soldiers who were no longer effective were to have the letters N.Y.D.N. (not yet diagnosed, nonefficient) entered on the field medical card. All cases were then to be sent to a special receiving centre where it was decided whether hospital treatment was needed. As Gwen Parsons has observed, diagnosis was made difficult by the fact that a symptom such as lethargy, one of the typical expressions of neurasthenia, could also be caused by a range of illnesses and infections. ${ }^{8}$ A century later, there is still debate about how to classify the impact of traumatic events. This was demonstrated in 2013 by changes in the 5 th edition of the American Psychiatric Association's Diagnostic and Statistical Manual for Mental Disorders, the DSM-5. Its updated diagnostic criteria for post-traumatic stress disorder now include more than 20 such criteria. ${ }^{9}$

\section{Shell Shock as Unconscious Dissent}

Carbery's account, published in 1924, is a lucid summary of the controversies at the time over shell shock. Among them was the extent to which it was more likely if soldiers were predisposed to a breakdown when stressed, or it was caused by physical trauma such as concussion from exploding shells. Many of the issues raised by Carbery remain at the forefront of discussions of shell shock and post-traumatic stress by contemporary historians such as Ben 
Shephard, ${ }^{10}$ Taylor Downing, ${ }^{11}$ and Tracey Loughran. ${ }^{12}$

Shell shock may also in some instances have been a form of involuntary or unconscious dissent. The evidence for this assertion is largely contextual, rather than drawn from soldiers' testimonies - the concept of involuntary or unconscious dissent implies that these men might not have been be able to characterise their own responses as dissent. An awareness of the limitations of self-reports can be seen in the findings of the 1922 British War Office Committee of Enquiry into Shell Shock, which included the observation that it was not possible to rely on soldiers' own descriptions of the reasons for their breakdown. ${ }^{13}$ These early reservations about the accuracy of soldiers' memories have been supported by subsequent research into posttraumatic stress among war veterans. Among the many variables linked to distortions of memory are the time since the original event, its severity, and the current clinical state of the person making the report. ${ }^{14}$

Sigmund Freud was a forceful advocate for the idea that shell shock could represent an unconscious form of dissent. His views were set out in a "Memorandum on the Electrical Treatment of War Neurotics," which comprised part of his testimony as an expert witness during a judicial inquiry in Vienna into abuses in the use of "electroshock." 15 This method had been used to persuade "war neurotics" to return to combat and it had been claimed that soldiers had died during the procedure. Freud drew attention to the pressures that might create an unconscious inclination to withdraw from the dangerous demands of active service. He pointed to the powerful emotional impacts of the fear of losing one's life, of being required to kill others, and of oppressive demands of superiors. In these circumstances, he said, a soldier might lose the power to exercise any form of agency over his own actions:

A soldier in whom these affective motives were very powerful and clearly conscious would, if he was a healthy man, have been obliged to desert or pretend to be ill. Only the smallest proportion of war neurotics, however, were malingerers; the emotional impulses which rebelled in them against active service and drove them into illness were operative in them without becoming conscious to them. ${ }^{16}$

What Freud described as "the emotional impulses which rebelled in them" were exacerbated by the new conditions experienced by soldiers in the First World War. The War Office Committee of Enquiry into Shell Shock acknowledged that "the use of high explosives and the violence and intensity developed in the recent War was wholly unknown in the conflicts of the past." 17 The authors of the report suggested that this was why they could not compare their findings on shell shock with any evidence about similar phenomena in previous campaigns. A lack of evidence from the past and the modernity of shell shock is more comprehensible if shell shock is understood as an extreme consequence of a transformation in the means of production. During the previous century, the factory had become increasingly important as the prototype for how labour was organised. Daniel Pick, in his War Machine: The Rationalisation of Slaughter in the Modern Age, follows Karl Marx in identifying the slaughterhouse as the metaphorical exemplar of this process. ${ }^{18}$ As Pick puts it, the type of new mechanised slaughterhouse described in Upton Sinclair's 1906 novel, The Jungle, combined "extraordinary technical advance with grotesquely primitive working conditions." 19 A similar human degradation and lack of control was experienced by soldiers in the trenches. Their situation was summed up by the cover design created by New Zealand artist, Len Lye, for the first edition in 1929 of Robert Graves' war memoir, Goodbye to All That. The design featured a photomontage that included an image of one of Lye's own sculptures, Tomb Cylinder. It looked like a 
madman's medical device, within which was trapped a small tree. This assemblage framed, in its turn, a sombre photo of Graves himself. It was a fitting expression of the inhuman instrumentality of new forms of warfare. ${ }^{20}$

When soldiers broke down, some authorities regarded their collapse as demonstrating they were too effeminate to embrace their aggressive urges, or that they were uncivilised degenerates. ${ }^{21}$ Poor morale, inadequate training, cowardice, malingering, an inherently weak disposition ("lacking in nerve stability") were also seen as causes of shell shock. ${ }^{22}$ In the immediate postwar period there were, however, analyses of the characteristics of shell shock that emphasised the biological consequences of prolonged stress and the limits of soldiers' capacity to cope. This emphasis on the somatic effects of trauma did not necessarily conflict with the psychodynamic approach of Freud. As Loughran has pointed out, both viewpoints acknowledged the role of powerful instincts and their emotional accompaniments. ${ }^{23}$

The testimony of the 59 witnesses in Britain who appeared in 1920 before the War Office Committee of Enquiry into Shell Shock ranged over all the possible situations that led to shell shock, as well as attempting to describe and categorise its symptoms. There was no concept of learned helplessness, the discovery by Martin Seligman and Steven Maier in the 1970s of the debilitating effects of a situation where the usual coping and problem-solving methods are perceived as futile. ${ }^{24}$ However, in language that foreshadowed the work of Seligman and Maier, Col. J. F. C. Fuller, Deputy Director of Staff Training, emphasised that shell shock was most likely to be seen when soldiers felt they had no control over events: "I think what produces shell shock much more than sudden danger is danger in a static position, where the man cannot get away from it." 25

These remarks summed up the acute situation to which soldiers were exposed during the new conditions of trench warfare. A similar point was made by the psychiatrist W. H. Rivers, who argued that stress was the principal cause of shell shock and this was greatest when a soldier had little to do and could not feel in charge, lacking "manipulative activity." ${ }^{26}$ John A. Lee's Civilian into Soldier includes an episode which typifies the indiscriminate destructiveness of warfare and the lack of manipulative activity. The narrator, John Guy, observes a cavalry attack against uncut wire and machine guns. Both men and horses are chopped to pieces, reduced to anonymous flesh. He concludes that the High Command were "helpless incompetents, blundering murderers, whose knowledge of war was only the knowledge of the inexhaustible reservoirs of flesh they were privileged to destroy . . . the High Command knew only the armchair and not the trench." 27 The High Command is represented as akin to the remote and incompetent manager of a giant abattoir, unrestrained by any losses, while the soldiers and horses are hapless participants in the action.

Auckland lawyer Leonard Leary, who was a gunnery subaltern at the time, recalls a similar occasion when he had to take horses and men across a battlefield pitted with craters to retrieve some abandoned German guns. The horses floundered in the debris, terrified at the sound of shellfire. Their drivers were "indignant at their well-loved horses being exposed to this useless risk." ${ }^{28}$ Neither horses nor men in these accounts have any say over their own fate. A similar perspective from the German side is presented in Ernst Johannsen's Fronterinnerungen eines Pferdes (A Horse's Memories of the Western Front), which appeared in 1929. ${ }^{29}$ Though the narrator-mare, Liese, sees the horses as casualties of the human desire for war, the ordinary soldiers in his novella are hardly less helpless.

Journal of New Zealand Studies NS27 (2018), 35-49

https://doi.org/10.26686/jnzs.v0iNS27.5175 
After the war, when veterans were freer to recall what it was like to be in France or Belgium, an insight into their experiences was given by the reception in New Zealand in 1929 of Erich Maria Remarque's novel Im Westen nichts Neues (All Quiet on the Western Front). Many of the letters that the New Zealand soldiers had sent home during the war indicated that they were confident they knew what they were fighting for. ${ }^{30} \mathrm{~A}$ decade later, however, there were veterans who publicly agreed that Remarque's anti-war novel was true to what they remembered, though others viewed it as an exaggeration of the degrading effects on the soldiers who had served in it. ${ }^{31}$ There were similar responses to Lee's novel, and several ex-servicemen, such as the historian J. B. Condliffe, praised its depiction of combat. ${ }^{32}$ Like many soldiers, Lee himself thought that he was not ready to review what the war meant until more than a decade afterwards.

Whatever the reactions of individual soldiers might have been, the indiscriminate destructiveness of the new machinery of war was overwhelming. It is illustrated by the caption Lee wrote for a series of photos in one of his scrapbooks. They show him in a group at Oatlands Park, a specialised hospital for amputees. It reads: "There were 750 men in the Limbless School, 500 legless, 250 armless." 33 The physical consequences of combat could be demonstrated in this fashion. The mental damage was not so immediately obvious.

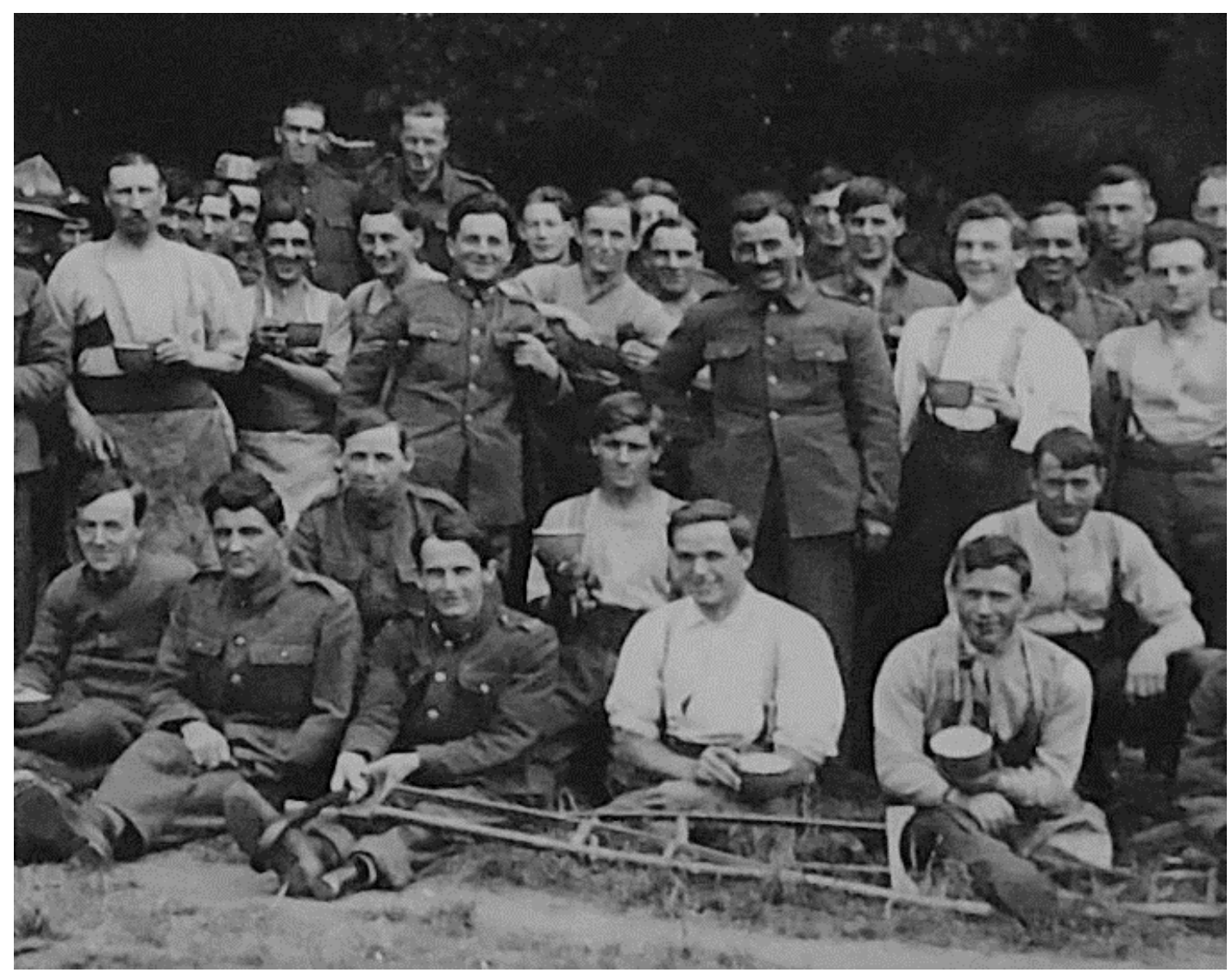

Figure 1: The Limbless School, Oatlands Park, 1918. Lee is seated second on left. NZMS 828 26/3. Sir George Grey Special Collections, Auckland City Library.

Journal of New Zealand Studies NS27 (2018), 35-49

https://doi.org/10.26686/jnzs.v0iNS27.5175 
It is not clear how many New Zealand soldiers were diagnosed during active service as having shell shock and what treatment they received while overseas, though there was a psychiatric unit at Brockenhurst, the principal hospital for wounded New Zealand soldiers. Nor is it evident whether New Zealanders tended to be given different diagnoses depending upon whether they were ordinary soldiers or officers; British officers with shell shock were likely to be seen as having symptoms consistent with neurasthenia, while hysteria was a commoner diagnosis for other soldiers. ${ }^{34}$ One possible source of information on shell shock among New Zealanders, the detailed fortnightly hospital reports published in issues of the soldiers' magazine Chronicles of the N.Z.E.F., indicates that few soldiers were being admitted after a diagnosis of shell shock. Between 27 June and 9 July of 1917 hundreds of men were admitted to the various divisions of the New Zealand General Hospital in England. At No. 3 General Hospital, Codford, which dealt with illnesses such as pneumonia, jaundice and appendicitis, one man is listed as suffering from neurasthenia, another from shell shock, but no other similar cases were recorded at the other hospitals during this period. ${ }^{35}$

The official history of the New Zealand Medical Service does mention the coercive methods to treat shell shock, such as disciplinary measures and "torpillage," the French term for the use of electric shocks to send supposed malingerers back to the battlefront. ${ }^{36}$ There is no indication, however, whether or not these had been used on New Zealand soldiers. ${ }^{37}$ The contrast between what was available in published accounts about New Zealand soldiers who broke down, and what actually happened, is indicated in Ormond Burton's work. In his history of the New Zealand Division, published in 1935, he briefly acknowledged the "limit to what men can endure" and suggested that this point was near during the disastrous winter of $1917-18 .^{38}$ This very general comment is very different from those in his unpublished memoir, A Rich Old Man, where he described what happened when men actually passed the limits of endurance. One of the common indicators of burnout was heavy drinking, but Burton thought smoking was a surer indication: "A cigarette to steady the nerves, then two, then three, then the chain effect. All the time the nicotine that apparently soothed was steadily undermining the nervous system until another brave man had to toss it in." 39

After 1916, most shell shock cases had been dealt with in France, according to the policy of PIE - "Proximity, Immediacy, and Expectation"-with the accent on returning as many soldiers as possible to active service. ${ }^{40}$ The actual situation that led to the trauma was of less concern than the continuing usefulness of the soldier, an approach claimed by Didier Fassin and Richard Rechtman to typify the attitude of the health services towards war neuroses. ${ }^{41}$ PIE, which was to become known as "forward psychiatry," became a model for the effective treatment of shell shock in later conflicts. The benefit any New Zealand serviceman might have gained from this new approach was likely to have been very limited. The orthodox view that PIE was a highly successful method has been challenged by a British analysis published in 2007 of the cases of over 3500 men admitted in 1917 to a centre near Ypres. Most of these soldiers were able to be retained in some role in the army, but only 20 percent of them were judged still fit for combat. ${ }^{42}$ The ongoing effects of shell shock were plain.

\section{Dissent Through Songs and Poetry}

If shell shock was an acute and solitary response to lack of control and horrific conditions at the Front, songs and poems provided milder and more acceptable outlets for the soldiers' feelings and a way of sharing them with others. The hero of Lee's novel, John Guy, who has been listening to a padre who claims God is on the Allied side, angrily interrupts, "You think 
God is happy when we stick a bayonet in Fritz?"43 The tension produced by Guy's belligerent remarks is relieved by a drunk who mocks the churchman after he leaves by singing some improvised lines from "Mademoiselle from Armentieres," possibly the most famous of all the wartime songs. It was still well-known in the 1950s by many New Zealand schoolboys:

The padres have a jolly good time, Parley Voo

The padres have a jolly good time, Parley Voo.

The padres have a jolly good time

With mademoiselle behind the line.

Inky Pinky Parley Voo. ${ }^{44}$

The ever-changing and usually obscene versions of songs like this were forms of resistance, in which targets such as NCOs and officers could be criticised or dismissed.

Many soldiers' songs were parodies of hymns such as "What a Friend We Have in Jesus," "Onward Christian Soldiers," or "Abide with Me."45 The song "Marching, Marching, Marching" was sung to the melody of the hymn "Holy, Holy, Holy, Lord God Almighty." Also known as "Grousing," it was banned by some officers if soldiers sang it while marching, and Chris Bourke, in his book Good-bye Maoriland: The Songs and Sounds of New Zealand's Great War, points out that such hymns were well known to most of the soldiers. ${ }^{46}$ Les Cleveland suggests that the sources from which soldiers could find the tunes for refrains like "We've Had No Beer" came from a common working-class culture of church, Sunday school, and chapel attendance. Singing songs based on familiar melodies may have had emotional overtones amounting to "a kind of furtive, secular prayer in the face of appalling suffering and danger." 47

In Lee's novel, Guy meets and eventually farewells a London prostitute, Ann. A refrain throughout the final chapter comes from the 1915 song "Good-bye-ee," which marks his coming return to the Front. This song was a popular item in music halls, places that were well patronised by soldiers on leave. ${ }^{48}$ "Good-bye-ee" satirises banal optimism, and includes the mordant line "I'll be tickled to death to go":

I'll be tickled to death to go.

Don't sigh-e. Don't cry-e. There's a silver lining in the sky-e.

Bon Soir, old thing. Cheerio, chin, chin,

Napoo, Toraloo, Goodbyeeeee. ${ }^{49}$

Lee chose this song over the well-known "Keep the Camp Fires Burning," which had been sung by troops departing New Zealand. The "silver lining" promised there is followed by the cheerful lines: "So turn the dark clouds inside out/Until the boys come home."

Many of the soldiers' poems that were published in the soldiers' magazine, Chronicles of the N.Z.E.F. also challenged the convention that uncomfortable topics like death and injury should be passed over or treated with manly fortitude. A comic treatment was possible, as in "Gold Stripe," a long complaint in the vernacular about the lack of recognition for ailments and injuries other than wounds- "little ills" like septic sores, shell shock, frostbite, and being gassed. ${ }^{51}$ The death of comrades was treated with more seriousness. In "Standing-To," a soldier begins by recalling images of the previous day, when he and a companion contemplated the beauty of the dawn and thought of "surf on distant shore." He contrasts these images with how he now sees his post: 
The ravaged earth, the shattered wall

No pleasure to my mind recall

My comrade's dead—old scenes seem new,

As now-alone-I'm standing-to. ${ }^{52}$

Truisms about military service and heroism were also questioned. In "Then," L. C. P. parodies Kipling's "If" and its final words, "you'll be a Man, my son!":

If you can love the staff in their galoshes,

And watch your best friends taken day by day,

If you are keen to try a fall with glory

And count the horrors lost in victory won,

No matter if you're Socialist or Tory,

You hurry up and take my place, my son. ${ }^{53}$

Such poems, formed, like the soldiers' songs, by experiences at the Front, are very different from the patriotic songs performed back in New Zealand. A 1917 song about bombardment, "When the Guns are Calling Yonder," which was sung by field artillerymen, concludes with the line, "And you'll never see your sweetheart any more." ${ }^{54}$ This fatalistic sentiment contrasts with many songs of jingoistic optimism. A piece for the piano, "Ye Sons of New Zealand," for example, warns that the "cubs" of the "old lion," the men from the "bush and the field," will "lay down the axe and the ploughshare, The weapons of death to yield." 55 The many patriotic songs composed in New Zealand during the war range from elegiac reflections on the sacrifices of the soldiers to more stirring injunctions to enlist. ${ }^{56}$ The savage irony that could be seen in some of the songs sung abroad contrasts with the light-hearted complaint of the song, "Army Stew" sung by soldiers of the Twelfth Infantry, as they marched over the Rimutaka Hill on their way to board a ship for Europe:

Army duff, Army duff,-

Privates don't get half enough;

Officers do, officers do;

They get puddings and we get stew. ${ }^{57}$

Songs and jokes relieved some of the sense of being controlled by the structure of military life. As Les Cleveland put it, while authority over the troops might be virtually omnipotent, it could still be "mocked by the powerless who can draw upon the total resources of popular culture to ridicule their leaders and assert their personal dignity." ${ }^{58}$ There was always a deeper knowledge as well, expressed in the song "We are the Ragtime Army," based on "We are Bill Massey's Army." One of the soldiers' versions dismisses any bragging by the survivors of Gallipoli:

You boast and spite from morn to night

And think you're very brave,

But the men who really did the job

Are dead and in their grave. ${ }^{59}$

\section{Back Home}

It took the return of veterans to New Zealand to bring home the reality that many New Zealand soldiers had suffered from shell shock. In 1924 more than 857 soldiers were still receiving pensions for psychological disability as the result of war service. ${ }^{60}$ The distance of this country from the theatre of war may explain why authorities were unprepared at first for the number of 
soldiers who still needed psychiatric care. John Weaver and David Wright have outlined the confusion when soldiers were placed in mental hospitals and suffered the accompanying stigma of "lunacy". There were, however, a few local psychiatrists with advanced training in dealing with the problems of veterans. Among them were individuals who were also prepared to argue that greater numbers of men needed treatment. ${ }^{61}$

In 1921, 65,000 men in Britain were still receiving mental health pensions for war disabilities. ${ }^{62}$ This gives some idea of the large numbers of British men who were affected immediately after the war, even allowing for the fact that many others could not establish that they were entitled to such a pension. ${ }^{63}$ Similar figures are not available for New Zealand, though a total of 22,349 men were receiving war pensions at 31 March 1921. This figure lumped together all veterans, even those from the New Zealand and Anglo-Boer Wars of the previous century. ${ }^{64}$ After 1924 , the New Zealand Pensions Department's Annual Reports included a category for war pensions being received for "functional nervous diseases (Neurasthenia and Hysteria)." ${ }^{65}$ The 857 men who were receiving such pensions on 31 March 1924 made up 5.9 percent of the 14,515 war pensions being paid at this time. The New Zealand numbers for enduring mental health disability were thus substantial (even if a few of these men may have been veterans of nineteenth century wars). Any idea that few New Zealanders would show evidence of mental breakdown, because of this country's masculinist tradition of not showing pain or weakness, is not supported by these figures. ${ }^{66}$ New Zealanders were like other soldiers.

The 1924 Report of the Pensions Department, however, contained a lengthy and apologetic explanation for why so many men were receiving pensions for mental disability. It contended that some recipients were exaggerating their condition so that that they could get the maximum pension. A common cause for the persistence of symptoms, however, was said to be the "undiscriminating solicitude of well-meaning associations and individuals," while many of the pensioners were described as having a weak nervous system in the first place. The department did, however, recognise that soldiers might suffer additional stress from the difficulty of reentering civilian life and from marital discord. ${ }^{67}$

This was a more grudging assessment than those seen by the readers of the newspapers of this period. Newspaper reports suggest that there was considerable sympathy towards such men. The popular language included phrases used in Parliament such as "nerves had been unsettled," "suffering mentally," and "mentally afflicted." 68 There were, however, less sympathetic views. Shell shock was also described as an excuse for abnormal conduct and "eminently curable," 69 and an excuse offered by criminals, ${ }^{70}$ and it was contended that the term should be replaced by "shell shy.",

Newspapers also covered the lobbying for better treatment of the affected men by the soldiers who had fought overseas, represented by branches of the Returned Servicemen's Association (RSA). Members of the RSA, formed in 1916, knew what it had been like in France or Belgium. The RSA was particularly alert to cases where soldiers had been sent to mental hospitals or annexes to such hospitals, rather than to more suitable institutions. ${ }^{72}$ Even before mass demobilisation, concerns about placing veterans in mental hospitals had led to the establishment of some centres for mild or borderline cases of mental illness among veterans. The best-known were at Karitane, near Dunedin, and Queen Mary Hospital at Hanmer Springs, where the bulk of the returned soldiers diagnosed with neurasthenia and hysteria were sent. 
Treatment at these specialist hospitals was generally humane and based upon rehabilitation through outdoor activities like gardening. Patients at Karitane were quartered until 1920 in a house belonging to the Medical Superintendent of nearby Seacliff Hospital, Dr Truby King, who was a believer in the importance of a healthy environment, exercise, and wholesome food in the treatment of mental illness. ${ }^{73}$ There was a larger building at nearby Puketeraki, which had individual rooms opening on to airy balconies overlooking the Karitane Peninsula. Nothing could contrast more with the conditions soldiers would have experienced in the trenches.

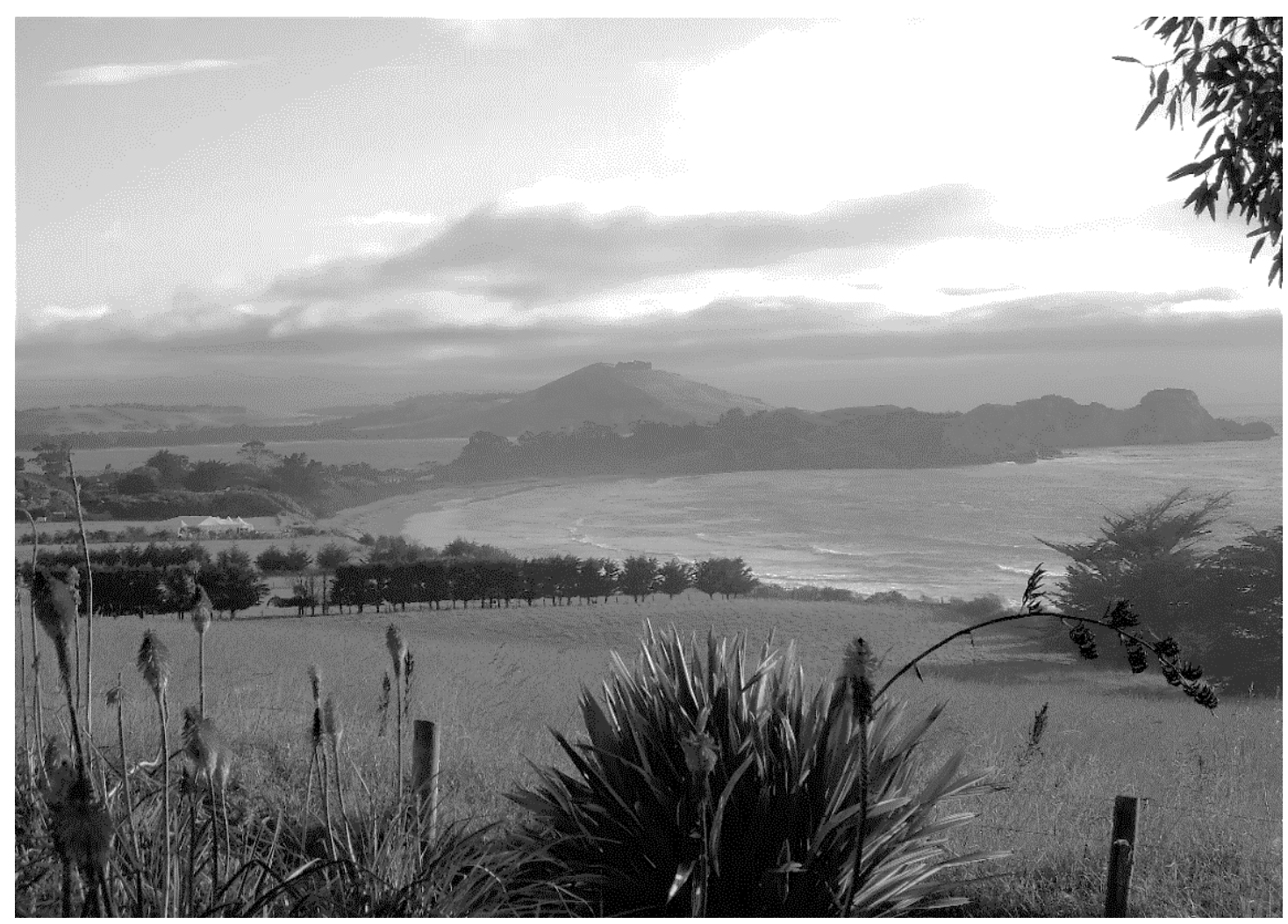

Figure 2: View from Puketeraki, 2012. Author's photo.

A comprehensive review by Gwen Parsons of how shell shock was regarded in New Zealand in the years after the war concludes that the general medical profession tended to see shell shock as a condition that was best treated by physical therapies, in line with a scientific model of insanity. ${ }^{74}$ In retrospect this is not surprising, as few New Zealand doctors were equipped to use the new "talking therapies" derived from the work of people like Freud and Carl Jung. However, in another overview of how perceptions about shell shock evolved in both Britain and New Zealand, Matthew Tonks suggests that the sheer number of shell shock cases and their visibility helped to shift public opinion away from prejudicial views of afflicted veterans at the same time as a concomitant move towards an acceptance of modern psychological techniques. Such tolerance was not so clearly seen in the Army. ${ }^{75}$

It became increasingly evident during the 1920s that thousands of veterans continued to have health problems. The Ex-Soldiers Rehabilitation Commission, 1929-30, which was set up to address some of the longer-term health and mental health consequences of military service, observed that it had been wrongly assumed that "all the sickness and impaired health due to war service had [already] manifested itself." After 166 interviews, the authors found several 
long-term health effects of military service, despite the fact that the men who served overseas had originally been selected on the basis of their superior fitness. Among these effects were "premature old age," "anxiety and despair," and a long list of illnesses, including heart disease, that appeared to be more prevalent among returned soldiers. ${ }^{76}$

More will be known about details of the history and treatment of individual soldiers who served in the First World War when their hospital files are released. Access is restricted until 100 years after file closure. These records may also provide some answers about what these soldiers felt about the reasons for their own breakdown, and the extent to which shell shock can be regarded as a defensive response for some of them - a form of involuntary dissent. Reports by New Zealand veterans from the current conflict in Afghanistan give some sense of the enduring psychological consequences of warfare. ${ }^{77}$ The language has changed, now that there is the diagnostic category of post-traumatic stress disorder, but the effects of active service are little different. $^{78}$

It may be hard ever to know quite how many First World War soldiers broke down with shell shock because this was the only way they could express a withdrawal from their role in the military. While there is a great deal of research about their post-war mental health, further work remains to be done about what happened during active service and whether the experiences and treatment of New Zealand soldiers diagnosed with shell shock were similar to those of the men from allied countries. More needs to be known, for example, about whether diagnoses for New Zealand soldiers followed the British class-based model, in which shell shock among enlisted men was likely to be regarded as a variant of hysteria, while officers were more likely to be diagnosed as suffering from neurasthenia. What we do know is that for hundreds of these men the mental health effects of their experiences persisted for many years. They were casualties like those remembered in the Animals in War Monument, near Brook Gate in Hyde Park. An inscription on that memorial reads: "They had no choice."

\section{Acknowledgements}

A version of this piece was originally presented as a paper at the August-September 2017 Conference on Dissent and the First World War, held at Victoria University of Wellington. Chris Bourke's authoritative Good-bye Maoriland: The Songs and Sounds of New Zealand's Great War has been a great help in expanding what I said then about soldiers' songs. Thanks also to Iain Sharp and Kate De Courcey for their assistance with the John A. Lee archive in the Sir George Grey Special Collections at the Auckland City Library and for permission to use the photo of Lee at Oatlands Park.

\footnotetext{
${ }^{1}$ The incidents in which soldiers actually rioted in protest were at training camps away from the Front. The best-known of these was the mutiny at Étaples in September, 1917, which was sparked by the arrest of a New Zealand gunner (Douglas Gill \& Gloden Dallas, "Mutiny at Étaples Base in 1917," Past and Present 69 [1975]: 88-112, http://www.jstor.org/stable/650297. Soldiers also burned huts and stores and sacked the officers' quarters at Sling Camp in in March 1919, after the men had objected to delays in being repatriated ("Riot at Sling Camp," Wanganui Herald, 13 May 1919, 7 , https://paperspast.natlib.govt.nz/newspapers/WH19190513.2.65

${ }^{2}$ Siegfried Sassoon, Memoirs of an Infantry Officer (London: Faber \& Faber, 1930), 196. Massingham is "Markington" in Sassoon's account.
} 
${ }^{3}$ Matthew Scott, "Soldiers' Letters as Testimonies of War," in Selected Student Essays on the Great War, ed. Jay Shulamith and Kate Hunter (Wellington: Victoria University History Department, 2009), $1-14$,

https://www.victoria.ac.nz/hppi/publications/selected-student-essays-on-the-great-war.pdf

${ }^{4}$ John A. Lee, NZMS 655: unpublished preface and history of Lee's war novels, p. 1. This preface accompanied an early draft written in 1930 of the second of Lee's war novels, Soldier. Lee's unpublished prefaces and commentaries on his war novels are held in the Sir George Grey Special Collections, Auckland City Library.

${ }^{5}$ Fritz von Unruh, quoted in Brian Murdoch, German Literature and the First World War: The AntiWar Tradition. Collected Essays by Brian Murdoch (Farnham, UK: Ashgate, 1915), 43.

${ }^{6}$ Lee, Civilian into Soldier (London: T. Werner Laurie, 1937), 208.

${ }^{7}$ Lt. Col. A. D. Carbery, The New Zealand Medical Service in the Great War 1914-1918: Based on Official Documents (Auckland: Whitcombe and Tombs, 1924), 319. All but one (hysteria) of these terms are no longer in use:

concussion neurasthenia: anxiety, fatigue, nervous irritability;

hysteria: conversion symptoms without a physical origin, such as paralysis of a limb or blindness;

pithiatism: a treatable variant of hysteria;

psychasthenia: a neurotic state marked by phobias, compulsions and obsessions;

psychic exhaustion: extreme fatigue caused by stress.

${ }^{8}$ Gwen A. Parsons, "The Construction of Shell Shock in New Zealand, 1919-1939: A Reassessment," Social History of Medicine 26, no. 1 (2012): 56-73.

${ }^{9}$ Matthew J. Friedman. "Finalizing PTSD in DSM-5: Getting from Here to There and Where to Go

Next," Journal of Traumatic Stress 26 (2013): 548-56.

${ }^{10}$ Ben Shephard, A War of Nerves (London: Jonathan Cape, 2000).

${ }^{11}$ Taylor Downing, Breakdown. The Crisis of Shell Shock on the Somme, 1916 (London: Little, Brown, 2016).

${ }^{12}$ Tracey Loughran, Shell Shock and Medical Culture in First World War Britain (Cambridge: Cambridge University Press, 2017).

${ }^{13}$ Report of the War Office Committee of Enquiry into Shell Shock (London: Army, 1922), 115. https://search.wellcomelibrary.org/iii/encore/record/C_Rb1829549

${ }^{14}$ Richard McNally, "Progress and Controversy in the Study of Posttraumatic Stress Disorder," Annual Review of Psychology 54 (2003):229-52.

${ }^{15}$ Sigmund Freud, "Memorandum on the Electrical Treatment of War Neurotics," presented to the Viennese Commission for the Investigation of Derelictions of Military Duty (1922), quoted in Kurt Eissler, Freud as an Expert Witness: The Discussion of War Neuroses between Freud and WagnerJauregg, trans. Christine Trollope (New York: International University Press, 1986), 23-28. The principal subject of the investigation was the Austrian military psychiatrist, Professor WagnerJauregg, a future winner of the Nobel Prize for Medicine.

${ }^{16}$ Freud, in Eissler, Freud as an Expert Witness, 25. Freud's view that people were often blind to their own motivation was also seen in his criticisms of treatment at spas for neurasthenia (popularly described as "nerves"), which he regarded as no better than a therapeutic fraud. He wrote that spa patients were often unaware of underlying difficulties, often sexual, for their prostration by "nerves." Soldiers diagnosed as suffering from neurasthenia had problems that were different from those of the spa patients, but Freud's memorandum to the enquiry in Vienna is consistent with his general view of unconscious motivation. See Horrocks, "'In their Nakeds': Katherine Mansfield, Freud and Neurasthenia at Bad Wörishoven," Journal of New Zealand Literature 32, no. 2 (2014): 121-42. ${ }^{17}$ Report of the War Office, 8. Suzie Grogan has argued that there are, in fact, some earlier recorded instances of war trauma similar to shell shock, especially in the Russo-Japanese War of 1904 and 1905, when "trench warfare, heavy bombardment and siege conditions" created an environment similar to that experienced in the First World War: Shell Shocked Britain: The First World War's Legacy for Britain's Mental Health (Barnsley, South Yorkshire: Pen and Sword History, 2014), 17.

Journal of New Zealand Studies NS27 (2018), 35-49

https://doi.org/10.26686/jnzs.v0iNS27.5175 
${ }^{18}$ Daniel Pick, War Machine, The Rationalisation of Slaughter in the Modern Age (New Haven and London: Yale University Press, 1993), 183-84. Pick quotes Marx's observation, in a letter to Engels, that: "Is there anywhere where our theory that the organisation of labour is determined by the means of production is more brilliantly confirmed than in the human slaughter industry?" (185).

${ }^{19}$ Pick, 129.

${ }^{20}$ Robert Graves, Goodbye to All That (London: Jonathan Cape, 1929). Tomb Cylinder (painted tin and cardboard), was exhibited with the Seven and Five Society. An exhibition of works from the Graves-Lye collaboration, On an Island: Len Lye, Robert Graves and Laura Riding, was shown at the Govett-Brewster Art Gallery, New Plymouth (April-August, 2017).

${ }^{21}$ Joanna Bourke, "Effeminacy, Ethnicity and the End of Trauma: The Sufferings of 'Shell-shocked' Men in Great Britain and Ireland, 1914-39," Journal of Contemporary History 28, no. 1 (2000): 5769.

${ }^{22}$ Christopher Pugsley, On the Fringe of Hell: New Zealanders and Military Discipline in the First World War (London: Hodder and Stoughton, 1991), 182. Pugsley notes that a British 2nd Army directive in late 1916 demanded that "lacking in nerve stability" could not be accepted as a reason for exemption from disciplinary action.

${ }^{23}$ Loughran, Shell Shock and Medical Culture, 182-209.

${ }^{24}$ Christopher Peterson, Steven Maier, and Martin Seligman, Learned Helplessness: A Theory for the Age of Personal Control (New York: Oxford University Press, 1995). Critical to the concept of learned helplessness is the importance of a perceived lack of control over events, though this has since been refined by research into individual differences in how people attribute causes for their own actions (their "explanatory styles").

${ }^{25}$ Report of the War Office, 29.

${ }^{26}$ Report of the War Office, 57.

${ }^{27}$ Lee, Civilian, 184. In an unpublished introduction to this novel, Lee emphasised that this scene was based on an actual event at Messines (NZMS 828, p. 4).

${ }^{28}$ Leonard Leary, Not Entirely Legal (Christchurch: Whitcoulls, 1977), 54.

${ }^{29}$ Brian Murdoch, "Bestial Humans and Humane Beasts: Ernst Johannsen's Vier von der Infanterie and Fronterinnerungen eines Pferdes, 1929," in Murdoch, German Literature and the First World War, 205-18.

${ }^{30}$ Glyn Harper, ed., Letters from the Battlefield. New Zealand Soldiers Write Home. 1914-18 (Auckland: Harper Collins, 2001), 155-56. Harper strongly affirms that the New Zealanders knew what they were fighting for and asserts that the letters he selected for his collection did not suggest that the men saw what they were doing as an "exercise in futility."

${ }^{31}$ The social impact in New Zealand of Remarque's work is discussed by Steven Loveridge in "Not so Quiet on the New Zealand Front: All Quiet on the Western Front and New Zealand Memories of the Great War," Journal of New Zealand Studies 18 (2014): 23-40.

${ }^{32}$ John Horrocks, "There is no Restraint in Murder. John A. Lee's War Novel Civilian into Soldier." Journal of New Zealand Literature, 34, no. 1 (2016): 54-79.

${ }^{33}$ Lee, NZMS 828 26/3.

${ }^{34}$ Downing, Breakdown, 90. This distinction may have been based on a difference between the way shell shock presented in men and officers, with the hysteric reaction more of a sudden collapse, while the neurasthenic symptoms of exhaustion and a lack of concentration were more a case of a slow loss of capacity. At the time, however, neurasthenia was regarded as a respectable condition experienced largely by over-stressed middle class people, hence its appropriateness for officers. This identification of neurasthenia with social class was first made by Charles Beard, who coined the term in his book American Nervousness: Its Causes and Consequences (New York: G.P.Putnam's Sons, 1881).

35 "Hospital Reports," Chronicles of the N.Z.E.F., 2, no. 22 (1917): 230-33. It is possible that this was because the action at Messines relieved the stress of being passive victims of enemy attacks. In Rivers' terminology, soldiers were able to engage in stress-reducing "manipulative activity." 
${ }^{36}$ Laurent Tatu, Julien Bogousslavsky, Thierry Moulin, Jean-Luc Shophard, "The 'Torpillage' Neurologists of World War 1: Electric Therapy to send Hysterics back to the Front," Neurology 75 no. 3 (2010): 279-83.

${ }^{37}$ Carbery, 318.

${ }^{38}$ Ormond Burton, The Silent Division: New Zealanders at the Front:1914-1919 \& Concerning One Man's War. ed. John Gray (Christchurch: John Douglas, 2014), 198.

${ }^{39}$ Burton, p. 418. Concerning One Man's War includes the previously unpublished sections of Burton's memoir that relate to his war service.

${ }^{40}$ Downing, Breakdown, 262.

${ }^{41}$ Didier Fassin and Richard Rechtman, The Empire of Trauma: An Inquiry into the Condition of Victimhood, trans. Rachel Gomme (Princeton: Princeton University Press, 2009), 47.

${ }^{42}$ Edgar Jones, Adam Thomas, and Stephen Ironside, "Shell Shock. An Outcome Study of a First World War 'PIE' Unit,” Psychological Medicine 37 (2007): 215-23.

${ }^{43}$ Lee, Civilian, 132.

${ }^{44}$ Lee, Civilian, 136.

${ }^{45}$ Soldiers' Songs of the First World War, https://www.bing.com/search?q=http\%2F\%2Fwww.westernfrontassociation.com\%2Fgreat-warpeople\%2Fbrothers-arms\%2F372-songs-war

${ }^{46}$ Chris Bourke, Good-Bye Maoriland: The Songs and Sounds of New Zealand's Great War (Auckland: Auckland University Press, 2017), 85.

${ }^{47}$ Les Cleveland, "Singing Warriors. Popular Songs in Wartime," Journal of Popular Culture 28, no. 3 (1994): 158. The conclusion of this particular comment is also quoted by Bourke, p. 85 .

${ }^{48}$ In late 1917, Lee himself was on leave in London, the home of the musical hall. In his novel Soldier he says that convalescent soldiers also had many opportunities to attend theatres-to fill unsold seats and swell audiences. John A. Lee, Soldier (Wellington: A. H. \& A. W. Reed, 1976), 127.

${ }^{49}$ Lee, Civilian, 293-95. The chapter's title is itself "Good-byeee." This song was composed and performed by R. P. Weston and Bert Lee.

50 "Soldiers' Songs. Music on the March. Some of the Favourites," Dominion, 27 April 1916, p.6. https://paperspast.natlib.govt.nz/newspapers/DOM19160427.2.44

${ }^{51}$ D. H. L., "Gold Stripe," Chronicles of the N.Z.E.F. 1, no. 8 (1916): 173.

${ }^{52}$ Hal Mack, "Standing-To," Chronicles of the N.Z.E.F. 2, no. 20 (1917): 177.

${ }^{53}$ L. C. P., "Then (With Apologies to Mr Kipling)," Chronicles of the N.Z.E.F. 1, no. 1 (1916): 13.

${ }^{54}$ Quoted in Les Cleveland, Dark Laughter: War in Song and Popular Culture (Westport, CO: Praeger, 1994), 120-21.

${ }^{55}$ Quoted in Steven Loveridge, Calls to Arms. New Zealand Society and Commitment to the Great War (Wellington: Victoria University Press, 2014), 122.

${ }^{56}$ Bourke, 157.

57 "Soldiers' Songs," 6.

${ }^{58}$ Cleveland, "Singing Warriors," 173.

${ }^{59}$ F. T. Nettleingham, Tommy's Tunes: A Comprehensive Collection of Soldiers' Songs, Marching Melodies, Rude Rhymes and Popular Parodies, 3rd ed. ( London: Erskine Macdonald, 1917), 43, quoted in Bourke, 88.

${ }^{60}$ Another 58 veterans were receiving pensions for "organic" nervous system disability. Twenty-sixth Annual Report of the Pensions Department. For the Year Ended March, 1924, Appendix to the Journals of The House of Representatives, 1 January, 1924, 8, https://paperspast.natlib.govt.nz/parliamentary/AJHR1924-I.2.3.5.21

${ }^{61}$ John Weaver and David Wright, 'Shell Shock and the Politics of Asylum Committal in New Zealand, 1916-22," Health and History 7, no. 1 (2005): 29-45.

${ }^{62}$ Downing, Breakdown, 292.

${ }^{63}$ Downing, Breakdown, 291-95. 
${ }^{64}$ Twenty-third Annual Report of the Pensions Department. For the Year Ended March 1921. Appendix to the Journals of the House of Representatives, 1 January, 1921, 7, https://paperspast.natlib.govt.nz/parliamentary/AJHR1921-I-II.2.3.2.22

${ }^{65}$ Twenty-sixth Annual Report, 8. Neurasthenia and hysteria were usually described as functional nervous disorders, as distinct from disorders that were thought to have an organic, rather than a psychological cause.

${ }^{66}$ This argument was put forward by Glyn Harper, in Massacre at Passchendaele: The New Zealand Story (Auckland: Harper Collins, 2000), 112-13.

${ }^{67}$ Twenty-sixth Annual Report, 9.

68 "Soldier Mental Cases. After-effects. Pandora's Box Open. Wear and Tear of War. Remarks by a Specialist," Evening Post, 22 February 1921, 8. https://paperspast.natlib.govt.nz/newspapers/eveningpost/1921/2/22/8

69 "Military Hospitals to Pass to Civilian Control," Ashburton Guardian, 16 June 1921, 8. https://paperspast.natlib.govt.nz/newspapers/AG19210616.2.54

70 "Shell-shock. An Excuse for Many Crimes," Auckland Star, 1 June 1918, 19. https://paperspast.natlib.govt.nz/newspapers/NOT19180410.2.49

71 "Shell Shock Cases. The Wrong Term Applied." NZ Herald, 12 June 1919, 8. https://paperspast.natlib.govt.nz/newspapers/NZH19190612.2.87.4

72 "Mental Treatment. The Soldier Patients," NZ Herald, 9 October 1919, 8. https://paperspast.natlib.govt.nz/newspapers/NZH19191009.2.100

${ }^{73}$ Cheryl Caldwell, "Truby King and Seacliff, 1889-1907," in Unfortunate Folk. Essays on Mental Health Treatment 1863-1992, ed. Barbara Brookes and Jane Thompson (Dunedin: Otago University Press, 2001), 35-48.

${ }^{74}$ Parsons, "The Construction of Shell Shock in New Zealand," 62.

${ }^{75}$ Matthew Tonks, "A comparative analysis of the developing reactions to 'shell shock' during and immediately after World War One in the medical, military and public sectors of British and New Zealand societies," in Selected Student Essays on the Great War, ed. Jay Shulamith and Kate Hunter (Wellington: Victoria University History Department, 2009), 65-84.

https://www.victoria.ac.nz/hppi/publications/selected-student-essays-on-the-great-war.pdf

${ }^{76}$ Neurasthenia and mental breakdown associated with war service were among the health effects that the Commission was tasked to investigate, with a focus on the capacity of impaired veterans to adequately maintain themselves and their dependants. H-39: 'Ex-Soldiers Rehabilitation Commission. Report of the Commission Appointed to Inquire Into And Report Upon The Position Of Physically and Economically Incapacitated Soldiers.' Appendix to the Journal of the House of Representatives, 1 January, 1930, 6. https://paperspast.natlib.govt.nz/parliamentary/AJHR1930-I.2.3.2.37

${ }^{77}$ Bevan Hurley, “The War Within," Sunday Star Times, August 27 2017, A7.

${ }^{78}$ The longer-term impacts of combat experience are now well researched. See, for instance, Lynda King, Daniel King, Kristin Vickers, Eve Davison, Avron Spiro III, "Assessing Late-Onset Stress Symptomatology among Aging Male Combat Veterans," Aging \& Mental Health 11 no. 2 (2007): 1975-91. 